\title{
Proliferative vitreoretinopathy: pathobiology, surgical management, and adjunctive treatment
}

\author{
David G Charteris
}

Surgical repair of rhegmatogenous retinal detachment is currently successful in over $90 \%$ of cases. ${ }^{1-4}$ Where there is a final failure to reattach the retina this is due to the development of proliferative vitreoretinopathy (PVR) in over $75 \%$ of cases. ${ }^{5-7}$ This process is characterised by cellular proliferation on both surfaces of the detached neuroretina, on the posterior vitreous face, and within the vitreous base resulting in the formation of contractile periretinal membranes. It is estimated to occur in 5-10\% of all rhegmatogenous retinal detachments. ${ }^{7}$

Initial clinical observations emphasised cellular activity in, and retraction of, the vitreous together with the appearance of retinal folds. The condition was referred to as massive vitreous retraction (MVR) or massive preretinal retraction (MPR) on the premise of the primary pathology being centred in the vitreous gel. ${ }^{8}$ This was later modified to massive periretinal proliferation (MPP) ${ }^{9}$ to acknowledge the role of periretinal membrane formation.

A unifying classification was published by the Retina Society Terminology Committee in $1983 .{ }^{7}$ This used the term proliferative vitreoretinopathy and has served as the basis for subsequent clinical and laboratory studies. It subdivides PVR into four stages (A-D) of increasing severity based on clinical features: vitreous haze and pigment, retinal stiffness and wrinkling, rolled edges of retinal breaks, vascular tortuosity, and fixed retinal folds advancing to a funnel retinal detachment. A revised form of this classification further subdivides the proliferative process by location (anterior/posterior) and type (focal/diffuse/subretinal/circumferential and anterior displacement). ${ }^{10}$

While these classifications have served to standardise the terminology and clinical descriptions used in dealing with PVR they are essentially anatomical and do not address the biological activity of the PVR process. Furthermore, they do not record clinically important information such as the number, size, and location of retinal breaks, factors known to be of significance in the risk of development and progression of PVR. ${ }^{11}$ The existing classifications therefore have limitations with respect to the comparison of the biological stage and the level of activity of the process between individual eyes in clinical or laboratory studies.

\section{Pathophysiology}

\section{CELLULAR CONSTITUENTS}

PVR can be viewed as a wound healing process in a specialised tissue. Various studies have addressed the question of the cellular composition of the periretinal membranes which are the central feature of the pathobiology. There is general agreement that four categories of cell can be identified (Table 1).

Retinal pigment epithelial (RPE) cells have been identified by light and electron microscopy ${ }^{12-14}$ and immunohistochemically. ${ }^{15-17}$ Experimental work has demonstrated the presence of proliferating RPE cells in an animal model of $\mathrm{PVR}^{9}$ and also that RPE cells within the eye may undergo metaplastic change to a macrophage or fibroblast-like morphology. ${ }^{18}{ }^{19}$ Clinical $^{20}$ and experimental ${ }^{21}$ studies have demonstrated that transscleral cryotherapy applied to eyes with retinal detachment enhances the dispersion of viable RPE cells into the vitreous cavity. Since there is a uniform presence of RPE cells in the contractile membranes formed in PVR this is potentially an important step in the pathogenesis of the condition.

Glial cells have been shown to be a part of PVR membranes. ${ }^{17} 22-24$ The cellular derivation of the glial component remains uncertain. Müller's cells, astrocytes, microglia, and perivascular glia have the potential to proliferate and contribute to periretinal membrane formation. It is notable that 'simple' glial epiretinal membranes may form in relation to retinal breaks and holes. ${ }^{12} 25$ These glial membranes can potentially provide a scaffold for the formation of the more complex membranes seen after retinal detachment.

Immunohistochemical study of epiretinal glia has shown that non-tractional membranes were purely glial, suggesting that other cellular components are necessary to produce the contractile and tractional properties of the periretinal membranes seen in PVR. ${ }^{24}$

Subretinal membranes are a further constituent of PVR. These can form as diffuse cell sheets or as taut membranes or bands ${ }^{26-28}$ and may prevent surgical reattachment of the retina. Light and electron microscopic studies of subretinal membranes have demonstrated diffuse subretinal sheets to be purely glial, ${ }^{29}$ whereas subretinal bands are formed by a mixed population of cells ${ }^{29-31}$ including RPE, fibroblastlike cells, macrophages, and glia. Immunohistochemical analysis has shown that a high percentage of these cells are RPE and that glial cells are a minor component. ${ }^{32}$

Most studies of PVR periretinal membranes have identified cells categorised as fibroblasts or fibrocytes. ${ }^{9} 12-1533$ Cells of fibroblastic morphology or cells which demonstrate an inconsistent or negative immunohistochemical staining for intermediate filaments (specifically glial fibrillary acidic protein and cytokeratin) have been shown to be the predominant cell type in some studies ${ }^{14} 1534$ 35; however, their derivation is not well established. It has been argued that they represent transformed $R P E^{913}$ or that

Table 1 Cell types involved in proliferative vitreoretinopathy

\begin{tabular}{ll}
\hline Cell & References \\
\hline Retinal pigment epithelium & $12-17,29-32$ \\
Glia & $12,17,22-25,29-32$ \\
Fibroblastic & $9,12-15,33-36$ \\
Inflammatory: & $14,16,34,35,38,39$ \\
$\quad$ Macrophages & $40-42$ \\
\hline Lymphocytes & \\
\hline
\end{tabular}


Table 2 Extracellular matrix components of proliferative vitreoretinopathy membranes

\begin{tabular}{ll}
\hline & References \\
\hline Collagen (types I, II, III, and IV) & $16,17,43$ \\
Heparan sulphate & 16,17 \\
Laminin & 16,17 \\
Fibronectin & $17,34,43,44$ \\
\hline
\end{tabular}

they may originate from vascular epithelial cells, glia, or hyalocytes. ${ }^{14} 15$ Given the evidence that the cells involved in PVR can change both in morphology ${ }^{1819}$ and immunohistochemical characteristics, ${ }^{35} 36$ the exact cellular derivation of all cells in PVR membranes is difficult to ascertain, and estimates of the relative numbers of each cell type may therefore be inaccurate. The fibroblastic cells may also contain myofibrils, ${ }^{13} 1433$ notably in recurrent epiretinal membranes ${ }^{37}$ and these cells may therefore be responsible for the contraction of PVR cellular membranes.

Inflammatory cells have consistently been identified as a component of PVR periretinal membranes. Initial morphological reports identified macrophages within membrane tissue. ${ }^{1434}$ Since there is experimental evidence that RPE cells can assume a macrophage-like morphology ${ }^{18}$ the origin of these cells has been further investigated. Immunohistochemical studies have confirmed the presence of macrophages in PVR membranes ${ }^{163638}$ and demonstrated that in more severe intraocular proliferation these tend to be of an acute inflammatory subtype. ${ }^{39}$

Recent studies have shown the presence of a population of lymphocytes within PVR tissue. ${ }^{40-42}$ Immunohistochemical analysis has shown that these are $\mathrm{T}$ lymphocytes of both CD4+ and CD8+ subsets, and that these cells may bear the IL-2 receptor activation marker. ${ }^{4041}$

\section{EXTRACELLULAR MATRIX}

The extracellular matrix composition of PVR periretinal membranes has also been analysed immunohistochemically 161743 (Table 2). These studies have demonstrated the consistent presence of interstitial collagens types I and III and a variable presence of type II (vitreous associated) collagen. It had been postulated that both RPE and glial cells may be responsible for the elaboration of the collagens present. ${ }^{17}$ The basal lamina proteins - type IV collagen, heparan sulphate, and laminin - have also been demonstrated, ${ }^{1617}$ notably where internal limiting membrane fragments are associated with the membrane specimen. ${ }^{16}$ The cell attachment protein fibronectin has been identified as a significant component of PVR membranes. ${ }^{173443}$ Fibronectin mRNA labelling and protein immunostaining have been demonstrated on retinal glia, RPE, and fibroblastic cells in PVR epiretinal membranes ${ }^{44}$ suggesting an intrinsic production of fibronectin by PVR tissue.

Clinically it has been observed that eyes with PVR have an increased tendency to develop marked intraocular fibrin formation after vitrectomy surgery. ${ }^{45} 46$ Experimental work has shown that fibrin contact causes RPE cells to dedifferentiate and migrate into a fibrin clot to form sheets of fibrocyte-like cells. ${ }^{47}$ Based on these observations it has been proposed that postoperative intraocular fibrin may form a surface for the formation of complex vitreal and epiretinal membranes with the resultant development of PVR.

\section{Membrane contraction}

Analysis of the constituents of the periretinal membranes formed in PVR, together with clinical observations and experimental studies, has led to an understanding of the pathobiological process. Retinal breaks may be associated with 'simple' glial epiretinal membranes; following retinal detachment there is a release of RPE cells and an associated breakdown of the blood-retinal barrier, ${ }^{48}$ effects which are accentuated by surgical intervention and in particular by cryotherapy. ${ }^{21} 4950$ There follows the formation of the complex periretinal and vitreous membranes containing the mixed cell types and extracellular matrix described above. It is the subsequent contraction of these membranes that is responsible for the clinical picture seen in PVR and for the potential failure of retinal reattachment surgery.

Based on the finding of fibroblastic cells, some of which have been demonstrated to contain cytoplasmic myofilaments, ${ }^{131533}$ it has been proposed that membrane shortening is mediated by intrinsic contraction of these component cells, thus producing the tractional forces found clinically in PVR. An in vitro system has shown that both RPE and fibroblasts, but not retinal glia, are capable of mediating the contraction of a type I collagen matrix by cellular mobility and subsequent attachment of collagen fibres. ${ }^{51}$

Experimental work has suggested an alternative mechanism of membrane contraction involving the interaction of RPE cells and collagen. ${ }^{52}$ In this scheme collagen fibres are pulled by the RPE cells by alternating extension and retraction of their lamellipodia (fibronectin serving as a bridge between RPE and collagen), collagen is piled up adjacent to the RPE cell with subsequent tissue shortening.

\section{The role of growth factors/cytokines}

Recent studies on the pathogenesis of PVR have investigated the mediators of the cellular events outlined above. Growth factors have the potential to regulate the chemotaxis, proliferation, contraction, and extracellular matrix elaboration by the cells involved in PVR and hence are likely to be centrally involved in its pathobiology. Results of growth factor/cytokine studies are summarised in Table 3.

In vitro experimental work has demonstrated that $\mathrm{RPE}$ cells can respond by mitogenesis and chemotaxis to vitreous derived fluid obtained after blood-retinal barrier

Table 3 Growth factors/cytokines in proliferative vitreoretinopathy (PVR)

\begin{tabular}{|c|c|c|c|c|c|c|c|c|c|c|c|}
\hline & $P D G F$ & $a F G F$ & $b F G F$ & $T G F \beta$ & $E G F$ & $T N F \alpha$ & $I G F 1$ & $I L-1$ & $I L-2$ & $I L-6$ & $I N F \gamma$ \\
\hline $\begin{array}{l}\text { In vitro activity (refs } 53,55,56,58 \text { ) } \\
\text { RPE chemotaxis } \\
\text { RPE proliferation } \\
\text { Glial cell chemotaxis }\end{array}$ & $\begin{array}{l}+ \\
+ \\
+\end{array}$ & $\stackrel{+}{-}$ & $\begin{array}{l}- \\
+ \\
-\end{array}$ & ^ & $\begin{array}{l}- \\
+ \\
-\end{array}$ & & + & + & - & & \\
\hline $\begin{array}{l}\text { Vitreous (refs 59-61) } \\
\text { Protein }\end{array}$ & & & & ++ & & ++ & & ++ & & ++ & ++ \\
\hline $\begin{array}{l}\text { PVR epiretinal membranes } \\
\text { Protein (refs 63-65, 67) } \\
\text { mRNA (ref 66) }\end{array}$ & + & + & & & + & + & + & + & & + & + \\
\hline
\end{tabular}

$\mathrm{RPE}=$ retinal pigment epithelium; $\mathrm{PDGF}=$ platelet derived growth factor; a/bFGF=acidic/basic fibroblast growth factors; TGF $\beta=$ transforming growth factor $\beta$; $\mathrm{EGF}=$ epidermal growth factor; TNF $\alpha=$ tumour necrosis factor $\alpha$; IGF1 =insulin-like growth factor 1 ; IL-1, IL-2, IL-6=interleukin $1,2,6$; IFN $\gamma=$ interferon $\gamma$ $+=$ identified/upregulated; $-=$ not found/absent; ${ }^{\star}=$ inhibition; $++=$ increased; (blank $=$ no data). 
breakdown was induced ${ }^{50}$ and that serum is an RPE chemoattractant. ${ }^{53}$ It has been shown that PVR vitreous stimulates RPE chemotaxis and proliferation and that this effect is greater in more advanced PVR. ${ }^{54}$ In vitro studies have also analysed the response of RPE and glial cells to individual growth factors. Interpretation of the results of these experiments is problematic since culture medium contents and cell culture density can affect the response of the target cell. In addition, the in vivo response of a given cell type will be modified by the interaction of growth factors and the type and amount of extracellular matrix.

RPE chemotaxis has been demonstrated in response to platelet derived growth factor (PDGF) ${ }^{53}$ and interleukin 1 (IL-1) ${ }^{55}$ but not to basic fibroblast growth factor (bFGF) and epidermal growth factor (EGF). ${ }^{53}$ Acidic and basic fibroblast growth factors (a/bFGF), EGF, PDGF, and insulin-like growth factor 1 (IGF-1) have been shown to stimulate DNA synthesis and cellular proliferation in cultured RPE and to be synergistic in this effect. ${ }^{56}$ In contrast, this response is inhibited by transforming growth factor $\beta$ (TGF- $\beta$ ) suggesting that growth factor effects on RPE are potentially a complex network of synergistic and antagonistic, positive and negative responses. ${ }^{56}$ Cellular responses are further modified by the local microenvironment - for example, the nature of the extracellular matrix. ${ }^{57}$ Retinal glial cells have also been shown to have a positive chemotactic response to PDGF but not to IL-1, IL-2, TGF- $\beta$, aFGF, bFGF, or EGF. 5558

Various studies have addressed the question of growth factor presence in vitreous, subretinal fluid, and periretinal membranes from eyes with PVR. Analysis of vitreous has shown the presence of elevated levels of IL-1, IL-6, tumour necrosis factor $\alpha$ (TNF $\alpha$ ), and interferon $\gamma$ (IFN $\gamma) .{ }^{59}$ TGF $\beta 2$ has been reported to be elevated in the vitreous in PVR $^{6061}$ although subsequent studies have failed to confirm this result. ${ }^{59}$ Cellular aspirates from PVR vitreous and subretinal fluid have demonstrated immunoreactivity to aFGF, EGF, IGF-1, and TGF $\beta 1.62$ It is, however, still uncertain whether the growth factor profile of vitreous reflects the growth factors active in the pathological processes in PVR membranes.

Immunohistochemical analysis of PVR epiretinal membranes has demonstrated the presence of aFGF, EGF, and IGF-1 protein localised to cells and extracellular matrix. ${ }^{6364}$ PDGF and PDGF receptors have been localised immunohistochemically to cells in PVR tissues. ${ }^{65}$ mRNA expression for the inflammatory growth factor TNF $\alpha$, IL $1 \beta$, and IL- 6 has been observed in cells in PVR membranes, ${ }^{66}$ as has IFN $\gamma$ protein. ${ }^{67}$ The cellular localisation of growth factor protein and mRNA is notable since it suggests that the cells in these membranes are involved in local growth factor production.

The demonstration of growth factors known to play a role in fibrosis and wound healing (FGF, TGF $\beta, P D G F$, EGF) and in inflammation (IL-1, IL-6, TNF $\alpha$ ) along with in vitro work showing an effect of these peptides on the possible target cells involved (although data on growth factor receptor expression in PVR tissues are limited) is suggestive of a role in the pathobiology of PVR. Potentially, growth factor mechanisms may hold the key to the imbalance of wound healing regulation seen in PVR. However, the exact roles of individual growth factors remain uncertain in what is likely to be a complex network of growth factor activity in the various stages of the evolution of PVR.

\section{Immune system involvement in PVR}

The demonstration of the presence of macrophages 16353839 and lymphocytes ${ }^{40-42}$ and the observation of MHC class II positive cells in PVR membranes ${ }^{38} 40-4268$ (both inflammatory and non-inflammatory cell types) has produced an increasing interest in the role of the immune system in the development in PVR.

Deposits of immunoglobulins and complement components have also been demonstrated on PVR epiretinal membranes ${ }^{38}$ and on pars plana biopsies taken from eyes with PVR. ${ }^{69}$ The cellular adhesion molecules CD11a, CD11c, CD18, ICAM-1, and LFA-1, which mediate the interaction of leucocytes with other cells and extracellular matrices, have also been found on PVR tissues. ${ }^{42} 70$

The observation of both cellular ${ }^{71} 72$ and humoral ${ }^{72}$ immune system responses to retinal antigens following retinal detachment and to the retinal antigens IRBP, S antigen, and opsin in an experimental model of PVR, ${ }^{73}$ and of anti-S antigen antibodies in the sera of patients with $\mathrm{PVR}^{74}$ has led to the view that an autoimmune reaction is involved in the ongoing pathobiology of PVR. In addition the finding of complement components in PVR vitreous ${ }^{75}$ and the known interaction between $T$ cells and RPE cells ${ }^{76}$ is suggestive of an immune system response.

The evidence for an autoimmune response in PVR, however, remains incomplete. Several studies have demonstrated that healthy controls have humoral and cellular immune responses to retinal $S$ antigen. ${ }^{77-79}$ Humoral and cellular responses to $S$ antigen have also been shown in diabetic patients following panretinal photocoagulation 8081 without the development of an ongoing intraocular inflammatory or autoimmune response.

$T$ lymphocytes and macrophages are fundamental cellular components of normal wound healing 8283 and have been shown to have a reciprocal interaction via growth factors in the wound healing process. ${ }^{84} 85$ Moreover, it has been shown that fibroblasts may produce a soluble factor which can prolong $\mathrm{T}$ cell survival ${ }^{86}$ and hence potentiate the role of $T$ cells at foci of fibrogenesis. The presence of cells involved in the immune response does not therefore imply an autoimmune mechanism as part of the pathogenesis of PVR. None the less, lymphocytes and macrophages have the potential to play a significant role in the development of PVR; mediating the pathobiology through growth factor secretion and the subsequent regulation of cellular chemotaxis and proliferation and the production of collagen, fibronectin, and other extracellular matrix components. $87-91$

\section{Surgical management of PVR}

The basic principles of the surgical treatment of retinal detachments complicated by PVR are those of detachment surgery in general - that is, the closure and sealing of retinal breaks and the complete release of periretinal traction. To these can be added the prevention of recurrence of the proliferative process and its ensuing tractional forces.

Retinal detachments in eyes with only minimal PVR may be treated successfully by an external scleral buckling procedure. ${ }^{92}$ However, expansile gas should be used with caution in such cases since there is evidence to suggest that this may increase the incidence and progression of PVR. ${ }^{93-95}$ Successful surgical reattachment of recurrent retinal detachments in the absence of advanced PVR can be achieved by modification of the scleral buckle in selected cases. ${ }^{96}$

In general, vitrectomy techniques are the basis of surgery for moderate to advanced PVR. Microsurgical manipulation allows the dissection and removal of epiretinal (and occasionally subretinal) membranes, thereby relieving tractional forces on the retina and permitting reattachment. Since cryotherapy is known to promote the dispersion of viable RPE cells and hence the progression of PVR. ${ }^{20} 21$ when possible laser photocoagulation is favoured to produce a chorioretinal adhesion around retinal breaks. 
In eyes where there is advanced PVR, anterior proliferation in the region of the vitreous base and around the preequatorial retina is often a prominent feature. ${ }^{10}$ Lewis and Aaberg have described the evolution of their surgical approach to such cases ${ }^{97}$ - initially vitreoretinal traction was relieved by a combination of vitrectomy and a high anterior scleral buckle, success rates were relatively low and a direct approach, dissecting and removing anterior PVR membranes was employed. Subsequently, anterior relaxing retinotomies were used to release traction. The use of retinotomy and retinectomy has now been extended to cases where there is very extensive epiretinal membrane formation, particularly strong membrane adhesions to retina or residual retinal traction following membrane dissection. Recent published series on PVR surgery have documented retinotomy rates of 2-40\% ${ }^{98-101}$ with an increased use of retinotomy and retinectomy in more severe PVR cases. Extensive retinectomy, however, exposes large areas of RPE and there is evidence of high reproliferation rates following this manoeuvre. ${ }^{102}$ Results from the Silicone Study Group suggest that in almost all cases eyes with severe PVR and without previous vitreous surgery can be managed without retinectomy. ${ }^{101}$

Perfluorocarbon liquids now provide a useful tool in the surgical management of PVR by allowing stabilisation of the retina to facilitate epiretinal membrane removal and the release of traction. ${ }^{103}$ In addition, they have been shown to be effective in attaining retinal flattening and in the positioning of large retinal flaps following retinotomy and/or retinectomy. ${ }^{104}$

Theoretically, since cells in PVR membranes have been demonstrated to be a source of extracellular matrix constituents and growth factors, ${ }^{4466}$ membrane removal either by dissection or retinectomy can markedly decrease the intraocular production of these components. This 'debulking' of PVR tissue could potentially break the ongoing cycle of further membrane production and contraction and is an argument for this form of direct surgical approach.

The Silicone Study Group has addressed the question of the optimal type of intraocular tamponade following vitrectomy for eyes with severe PVR. Comparison of silicone oil with sulphur hexafluoride $\left(\mathrm{SF}_{6}\right)$ gas showed a statistically significant advantage of oil over gas both in terms of visual acuity and posterior retinal reattachment. ${ }^{105}$ No such advantage was found in comparing silicone oil with perfluoropropane $\left(\mathrm{C}_{3} \mathrm{~F}_{8}\right)^{106}$; indeed there was an advantage of borderline significance in favour of perfluoropropane in achieving anatomical reattachment. The rate of postoperative hypotony was lower in the silicone oil compared with the gas groups but it is notable that oil was removed in only $45 \%$ of cases in the recent report of this group. ${ }^{107}$

The effect of intraocular tamponade on the proliferative process is as yet uncertain. Studies on the use of silicone oil after vitrectomy in eyes with PVR have reported a high rate of retro-oil epiretinal membrane reproliferation, ${ }^{108}$ particularly in association with large retinectomies. ${ }^{102} 109$ Histopathological study of the membranes formed has shown silicone oil droplets within membrane extracellular matrix ${ }^{109110}$ which persists after oil removal. Potentially, silicone oil could downregulate membrane formation by limiting access of cells and growth factors to the retinal surface or may produce upregulation by compartmentalising these in contact with the retina. Experimental animal work has shown that silicone oil does not prevent epiretinal membrane formation. ${ }^{11-113}$ Moreover, one study has documented an increased incidence of membrane formation and tractional retinal detachment in oil filled compared with perfluoropropane or fluid filled eyes ${ }^{114}$ with a corresponding increased RPE mitogenic effect of silicone oil associated vitreous cavity fluid.
Table 4 Proliferative vitreoretinopathy: adjunctive treatment

\begin{tabular}{ll}
\hline & References \\
\hline Antiproliferative agents & \\
5-Fluorouracil & $118-122$ \\
Daunorubicin & $123-125$ \\
Retinoids & $131-134,160$ \\
Taxol & 135 \\
Antitransferrin immunotoxin & 137 \\
Carmustine & 159 \\
Colchicine & $152-154$ \\
Irradiation & $128-130$ \\
Anti-inflammatory agents & $138-144$ \\
Corticosteroids & 118,138 \\
Non-steroidal & 145 \\
Cyclosporin A & $45,146-148$ \\
Heparin/low molecular weight heparin & 149 \\
Tissue plasminogen activator & 150 \\
Growth factor regulators & \\
\hline
\end{tabular}

The clinical significance of the reproliferative effect of silicone oil remains unresolved although the results of the Silicone Study Group ${ }^{106}$ would suggest that oil and perfluoropropane gas do not greatly differ in their potential to produce reproliferation and subsequent surgical failure.

As vitreoretinal surgical techniques have advanced the anatomical success rate of retinal surgery in severe PVR has increased from around $60 \%$ to over $90 \%$ in recently reported series. ${ }^{9899115}$ Visual results, however, are often disappointing and the value of such surgery has been questioned. Analysis of the results of PVR surgery has shown that unilaterally aphakic eyes seldom achieve beneficial vision following complex PVR surgery and that subjective visual comfort is often poor owing to diplopia and photophobia. ${ }^{116}$ Despite this most patients report that surgery was worthwhile. ${ }^{116117}$

\section{Adjunctive treatment}

Studies on the pathobiology of PVR have identified the elements involved - fibrin deposition, cellular accumulation and proliferation, production of extracellular matrix, and contraction of the membranes formed. It has become possible to design pharmacological adjuncts to the surgical management of the condition which specifically target the cellular components and pathological processes of PVR (Table 4).

NON-SPECIFIC ANTIPROLIFERATIVE AGENTS

The proliferation of the cellular subtypes (RPE, glia, fibroblastic cells, and inflammatory cells) is a key stage in the progression of PVR. Various pharmacological agents are available which will inhibit the proliferation of the cells involved in PVR either through a general antiproliferative effect or via inhibition of a specific cellular type.

The antiproliferative agent 5-fluorouracil (5-FU) has been shown to be effective in reducing the incidence of PVR in animal models ${ }^{118119}$ and appears to be relatively non-toxic at the levels required to be effective in experimental eyes. ${ }^{118120}$ A prospective study in human eyes using a single intravitreal injection of a high dose of $5-\mathrm{FU}(10 \mathrm{mg})$ at the completion of vitrectomy for PVR ${ }^{121}$ demonstrated that this dosage was well tolerated, a result also found in a previous study using $1 \mathrm{mg}$ of intravitreal 5-FU ${ }^{122}$; however, surgical success was not improved in the treated groups.

The efficacy of other antiproliferative agents in PVR has also been investigated. Daunorubicin (daunomycin) has been tested both experimentally and clinically. In an experimental animal model of PVR daunomycin prevented retinal detachment if injected at the time of PVR induction or in two doses 3 days later. ${ }^{123}$ Uncontrolled clinical studies have been carried out using an infusion of daunomycin $7.5 \mathrm{mg} / \mathrm{l}$ for 10 minutes at the time of vitrectomy surgery on PVR following both trauma and 
rhegmatogenous retinal detachment. ${ }^{124} 125$ Results indicate that this dosage appears to be well tolerated and produced surgical success rates which the authors felt improved on their previous work. A multicentre European trial is currently being conducted to investigate the potential role of daunomycin as an adjunct in PVR management. ${ }^{126}$

The ocular toxicity of a range of antiproliferative agents has been investigated experimentally ${ }^{127}$; however, data on the clinical efficacy and safety of the majority of antiproliferative drugs are limited at present.

Ocular irradiation has been proposed as a potential therapeutic option in the treatment of PVR. In vitro studies have shown that low dose irradiation can markedly inhibit RPE cell division ${ }^{128}$ and animal work has demonstrated that low dose irradiation given early or late in the proliferative process can reduce the incidence of tractional retinal detachment. ${ }^{129}$ A prospective clinical study, however, failed to demonstrate a significant beneficial effect of postoperative irradiation (with a relatively high dose of $3000 \mathrm{cGy}$ ). ${ }^{130}$ No radiation retinopathy was reported after 3 years although this complication might develop at a later stage.

\section{SPECIFIC ANTI-PROLIFERATIVE AGENTS}

The proliferation and phenotypic change seen in RPE cells after retinal detachment and in PVR may be due to the depletion of retinoid input to these cells. In vitro work has shown that retinoic acid produces a growth arrest in RPE cell cultures and prevents the dedifferentiation of individual RPE cells. ${ }^{131}$ In addition to the specific effects on RPE cells retinoids can also modulate the differentiation of other cell types.

The role of retinoids has been investigated in animal models of PVR and it has been shown that retinoic acid can reduce the rate of tractional retinal detachment when delivered to the vitreous cavity in silicone ${ }^{132}$ and loaded in microspheres of biodegradable polymer. ${ }^{133}$ Oral retinoic acid is currently used in the treatment of skin disorders and is relatively non-toxic. An initial report on the use of oral 13-cis retinoic acid as an adjunct to surgery in PVR has shown a promising result ${ }^{134}$ and further reports on the efficacy of this agent are awaited.

Taxol is an agent which stabilises microtubules and blocks the G2 and $M$ phases of the cell cycle. It has been shown to inhibit fibroblast replication, migration, and contraction. An experimental study has shown that a single dose of taxol is effective in reducing the rate of tractional retinal detachment in PVR. ${ }^{135}$ Drugs aimed specifically at fibroblast activity may have a role to play in PVR management.

Immunohistochemical analysis has shown that cells in PVR epiretinal membranes express transferrin receptors. ${ }^{136}$ Proliferating cells are known to upregulate their transferrin receptor expression and in vitro experimental work has demonstrated that antitransferrin receptor monoclonal antibodies conjugated to an immunotoxin selectively inhibit proliferating RPE cells, ${ }^{137}$ thus providing another selective antiproliferative treatment for PVR.

\section{ANTI-INFLAMMATORY THERAPY}

Corticosteroids are a potential adjunctive therapy for PVR since they modify both cellular proliferation and the inflammatory response, two major pathophysiological processes of PVR. In vitro studies have suggested that steroids may have a bimodal effect on ocular fibroblast proliferation with increased proliferation at low dosage and a reduction in proliferation at high dosage. ${ }^{138}$ Studies on
RPE cell proliferation have shown a non-significant reduction in proliferation. ${ }^{139}$ Animal studies, however, suggest that intravitreal injections of dexamethasone $e^{140}$ or triamcinolone ${ }^{141142}$ reduce intraocular cellular proliferation and tractional retinal detachment. This action may be largely mediated by a reduction in blood-retinal barrier breakdown and associated intraocular inflammation. A prospective, controlled study using high dose systemic steroids starting 5 days postoperatively has shown a benefit in mild but not advanced PVR ${ }^{143}$ and dexamethasone has been reported to be non-toxic when injected into the vitreous cavity after vitrectomy. ${ }^{144}$ Good data on the efficacy of perioperative steroid treatment in the clinical setting are awaited.

Other approaches to downregulate the inflammatory component of PVR may also be of value. Non-steroidal anti-inflammatory medications given perioperatively could limit the degree of blood-retinal barrier breakdown and have been shown to inhibit cellular proliferation in vitro. ${ }^{138}$ Experimental work has additionally demonstrated an additive effect of indomethacin when given with 5-FU.118 Again clinical data are lacking at present. The demonstration of $\mathrm{T}$ lymphocytes and other immune components in PVR tissues ${ }^{38} 40-4268$ suggests that immunomodulation might provide an adjunctive treatment for PVR. Preliminary results of animal work using dexamethasone and the specific $\mathrm{T}$ cell inhibitor cyclosporin $\mathrm{A}$ have shown a reduction in PVR progression with this combined treatment but no additive effect. ${ }^{145}$

MODULATION OF FIBRIN PRODUCTION

Another possible target for adjunctive treatment is the prevention of fibrin formation associated with blood-retinal barrier breakdown seen after vitreoretinal surgery. A clinical trial of the use of heparin to prevent postoperative fibrin formation demonstrated a reduction following intravitreal infusion of heparin $10 \mathrm{IU} / \mathrm{ml}$, but an associated increased incidence of intraoperative bleeding, ${ }^{45} 5 \mathrm{IU} / \mathrm{ml}$ infusion, and intravenous heparin had no significant effect. Low molecular weight heparin is thought to produce fewer haematological complications for an equal antithrombotic effect $^{146}$ and has been shown experimentally to reduce fibrin formation after vitrectomy. ${ }^{147}$ In addition, heparin interferes with cell-substrate adhesion by binding fibronectin, binds growth factors including FGFs, EGF, and PDGF, and inhibits cellular proliferation including scleral fibroblasts and RPE cells. ${ }^{146}$ These combined activities make heparin (ideally low molecular weight heparin) a potential multifunctional drug for use in the prevention of the development of PVR. Preliminary reports on animal studies suggest that low molecular weight heparin does reduce the rate of tractional retinal detachment caused by PVR. ${ }^{148}$

Clinical work has shown that formed intraocular fibrin can be effectively dissolved by tissue plasminogen activator (tPA) ${ }^{149}$ without significant side effects. As yet there are no data on whether treatment with tPA influences the subsequent development of PVR.

\section{Growth factor regulation}

Growth factors are likely to play a central role in the pathobiological processes of PVR as described above. The inhibition or blocking of growth factor mediated cellular activity is a treatment with the potential to selectively target the aberrant cellular proliferation seen in PVR while sparing physiological ocular wound healing. At present growth factor blocking agents are of limited availability but in vitro work has demonstrated the ability of protamine, 
histone IIB, pentosan polysulphate, and polylysine as well as heparin to block growth factor mediated RPE cell chemotaxis and DNA synthesis. ${ }^{150}$

\section{Prevention of membrane contraction}

PVR periretinal membrane contraction is responsible for retinal traction and shortening and consequent surgical failure, and is an additional possible target for pharmacological intervention. As described above heparin blocks cell substrate adhesion (via fibronectin) and can therefore prevent membrane contraction. ${ }^{146}$ An in vitro study has demonstrated the inhibition of fibroblast mediated contraction of collagen gels by vitamin A, retinoic acid, and n-butyrate. ${ }^{151}$ The potential of these and other agents to modulate the progression of PVR via inhibition of membrane contraction has not yet been fully investigated. The antiproliferative agent colchicine has been shown to be effective in inhibiting RPE cell contractility in vitro ${ }^{152}$ and to reduce experimental retinal detachment and PVR. ${ }^{153} \mathrm{~A}$ prospective clinical study using low dose oral colchicine as an adjunct to surgery for PVR failed, however, to show any benefit of colchicine treatment. ${ }^{154}$

\section{Drug delivery}

A major limitation to the successful treatment of PVR using pharmacological adjuncts is the difficulty in achieving therapeutic drug levels in the microenvironment of the retinal surfaces over a sufficiently long period to adequately inhibit periretinal membrane formation. Single intravitreal injections of antiproliferative agents have a relatively short half life (further shortened by vitrectomy, aphakia, and postoperative inflammation) ${ }^{139}$ which is unlikely to be sufficient for an adequate therapeutic effect.

Recently sustained drug-delivery systems have been used in trials both experimentally and clinically. Biodegradable polymers ${ }^{155} 156$ and slow release reservoirs ${ }^{157} 158$ have provided adequate drug levels and appear to be relatively non-toxic. An additional possibility in PVR surgery is the use of silicone oil (or other future tamponade agents) as a vehicle for drug delivery and the lipophilic antiproliferative agent carmustine has been shown to reduce experimental PVR when delivered in this way. ${ }^{159}$ Preliminary data on the experimental use of retinoic acid in a silicone oil/fluorosilicone copolymer (to produce an even drug delivery within the eye) have been encouraging. ${ }^{160}$

\section{Conclusion}

The management of PVR is time consuming and resource intensive. Although surgical success rates have improved dramatically in the past 15 years visual results are often disappointing. Despite this, vitreoretinal surgeons feel justified in continuing to operate on this complex surgical problem and patients with PVR view their attempts as worthwhile.

Future resources must be aimed, firstly, at the prevention of this vexed complication of retinal detachment by appropriate surgical repair. Additionally, the identification of high risk cases, whether untreated primary detachments or failed primary repairs, will have increasing importance as pharmacological adjuncts become available both for prophylaxis and as an addition to vitreoretinal surgery. A range of adjunctive agents is currently available and data on the efficacy of these drugs are urgently needed. Investigation of the optimal mechanisms of delivery for such agents will also advance the future management of PVR.
The author wishes to acknowledge the contributions of Professor I Grierson, Dr P Hiscott, Professor D McLeod, and Dr M Boulton for his understanding of this subject.

Vitreoretinal Unit,

DAVID G CHARTERIS

Moorfields Eye Hospital,

City Road, London EC1V 2PD

1 Tani P, Robertson DM, Langworthy A. Rhegmatogenous retinal detachment without macular involvement treated with scleral buckling. $A m \mathcal{F}$ Ophthalmol 1980; 90: 503-8.

2 Tani P, Robertson DM, Langworthy A. Prognosis for central vision and anatomic reattachment in rhegmatogenous retinal detachment with macula detached. Am $\mathcal{f}$ Ophthalmol 1981; 92: 611-20.

3 Stanford MR, Chignell AH. Surgical treatment of superior bullous rhegmatogenous retinal detachments. Br f Ophthalmol 1985; 69: 729-32.

4 Gilbert C, McLeod D. D-ACE surgical sequence for selected bullous retinal detachments. Br f Ophthalmol 1985; 69: 733-6.

5 Chignell AH, Fison LG, Davies EWG, Hartley RE, Gundry MF. Failure in retinal detachment surgery. Br $₹$ Ophthalmol 1973; 57: 525-30.

6 Rachal WF, Burton TC. Changing concepts of failure after retinal detachment surgery. Arch Ophthalmol 1979; 97: 480-3.

7 The Retina Society Terminology Committee. The classification of retinal detachment with proliferative vitreoretinopathy. Ophthalmology 1983; 90: 121-5.

8 Machemer R. Proliferative vitreoretinopathy (PVR): a personal account of its pathogenesis and treatment. Invest Ophthalmol Vis Sci 1988; 29: 1771-83.

9 Machemer R, Laqua H. Pigment epithelial proliferation in retinal detachment (massive periretinal proliferation). Am $f$ Ophthalmol 1975; 80: $1-23$.

10 Machemer R, Aaberg TM, MacKenzie Freeman H, Irvine AR, Lean JS, et al. An updated classification of retinal detachment with proliferative vitreoretinopathy. Am $\mathcal{F}$ Ophthalmol 1991; 112: 159-65.

11 Cowley M, Conway BP, Campochiaro PA, Kaiser D, Gaskin H. Clinical risk factors for proliferative vitreoretinopathy. Arch Ophthalmol 1989; 107: $1147-51$

12 Clarkson JG, Green WR, Massof D. A histopathological review of 168 cases of preretinal membrane. Am f Ophthalmol 1977; 84: 1-17.

13 Machemer R, van Horn DL, Aaberg TM. Pigment epithelial proliferation in human retinal detachment with massive periretinal proliferation. $\mathbf{A m} \mathcal{F}$ Ophthalmol 1978; 85: 181-91.

14 Kamplik A, Kenyon KR, Michels RG. Epiretinal and vitreous membranes. A clik A, Kenyon KR, Michels RG. Epiretinal and vitreous membranes.

15 Hiscott PS, Grierson I, McLeod D. Retinal pigment epithelial cells in epiretinal membranes: an immunohistochemical study. Br $\mathcal{f}$ Ophthalmol 1984; 68: 708-15

16 Jerdan JA, Pepose JS, Michels RG, Hayashi H, De Bustros S, Sebag M, et al. Proliferative vitreoretinopathy membranes. An immunohistochemical study. Ophthalmology 1989; 96: 801-10.

17 Morino I, Hiscott PS, McKechnie N, Grierson I. Variation in epiretinal membrane components with clinical duration of the proliferative tissue. Br ₹Ophthalmol 1990; 74: 393-9.

18 Mueller-Jensen K, Machemer R, Azarnia R. Autotransplantation of retinal pigment epithelium in intravitreal diffusion chambers. Am 7 Ophthalmol 1975; 80: 530-7.

19 Mandelcorn MS, Machemer R, Fineberg E, Hersch SB. Proliferation and metaplasia of intravitreal retinal pigment epithelial cell autotransplants. Am $\mathcal{f}$ Ophthalmol 1975; 80: 227-37.

20 Glaser BM, Vidaurri-Leal J, Michels RG, Campochiaro PA. Cryotherapy during surgery for giant retinal tears and intravitreal dispersion of viable retinal pigment epithelial cells. Ophthalmology 1993; 100: 466-70.

21 Campochiaro PA, Kaden IH, Vidaurri-Leal J, Glaser BM. Cryotherapy enhances intravitreal dispersion of viable retinal pigment epithelial cells. Arch Ophthalmol 1985; 103: 434-6.

22 Rodrigues MM, Newsome DA, Machemer R. Further characterization of epiretinal membranes in human periretinal proliferation. Curr Eye Res $1981 ; 1: 311-5$

23 van Horn DL, Aaberg TM, Machemer R, Fenzl R. Glial cell proliferation in human retinal detachment with massive periretinal proliferation. $A m \mathcal{F}$ Ophthalmol 1977; 84: 383-93.

24 Hiscott PS, Grierson I, Trombetta CJ, Rahi AHS, Marshall J, McLeod D. Retinal and epiretinal glia - an immunohistochemical study. $\mathrm{Br} \mathcal{F}$ Ophthalmol 1984; 68: 698-707.

25 Foos RY. Vitreoretinal juncture: simple epiretinal membranes. Graefes Arch Clin Exp Ophthalmol 1974; 189: 231-50.

26 Machemer R. Surgical approaches to subretinal strands. Am $\mathcal{f}$ Ophthalmol 1980; 90: 81-5.

27 Sternberg P, Machemer R. Subretinal proliferation. Am 7 Ophthalmol 1984; 98: 456-62.

28 Hiscott P, Grierson I. Subretinal membranes of proliferative vitreoretinopathy. Br f Ophthalmol 1991; 75: 53.

29 Wilkes SR, Mansour AM, Green WR. Proliferative vitreoretinopathy. Histopathology of retroretinal membranes. Retina 1987; 7: 94-101.

30 Trese MT, Chandler DB, Machemer R. Subretinal strands: ultrastructural features. Graefes Arch Clin Exp Ophthalmol 1985; 223: 35-40.

31 Schwartz D, De La Cruz ZC, Green WR, Michels RG. Proliferative vitreoretinopathy. Ultrastructural study of 20 retroretinal membranes removed by vitreous surgery. Retina 1988; 8: 275-81.

32 Hiscott P, Morino I, Alexander R, Grierson I, Gregor Z. Cellular components of subretinal membranes in proliferative vitreoretinopathy. Eye 1989; 3: 606-10.

33 Walshe $R$, Esser $P$, Wiedemann $P$, Heimann $K$. Proliferative retinal diseases: myofibroblasts cause chronic vitreoretinal traction. $\mathrm{Br} f$ Ophthalmol 1992; 76: 550-2

34 Hiscott PS, Grierson I, McLeod D. Natural history of fibrocellular epiretinal membranes: a quantitative, autoradiographic, and immunohistochemical study. Brf Ophthalmol 1985; 69: 810-23.

35 Vinores SA, Van Neil E, Kim HJ, Campochiaro PA. Simultaneous expression of keratin and glial fibrillary acid protein by the same cells in epiretinal membranes. Invest Ophthalmol Vis Sci 1992; 33: 3361-6.

36 Vinores SA. Ultrastructural and immunocytochemical changes in retinal pigment epithelium, retinal glia, and fibroblasts in vitreous culture. Invest Ophthalmol Vis Sci 1990; 31: 2529-45. 
37 Maguire AM, Smiddy WE, Nanda SK, Michels RG, de la Cruz Z, Green WR. Clinicopathologic correlation of recurrent epiretinal membranes after previous surgical removal. Retina 1990; 10: 213-22.

38 Baudouin C, Fredj-Reygrobellet D, Gordon WC, Baudouin F, Peyman G, Lapalus $P$, et al. Immunohistologic study of epiretinal membranes in proliferative vitreoretinopathy. Am $\mathcal{f}$ Ophthalmol 1990; 110: 593-8.

39 Esser P, Heimann K, Wiedemann P. Macrophages in proliferative vitreoretinopathy and proliferative diabetic retinopathy: differentiation of subretinopathy and proliferative diabetic retinopat.

40 Charteris DG, Hiscott P, Grierson I. Lightman SL. Proliferative vitreoretinopathy: lymphocytes in epiretinal membranes. Ophthalmology 1992; 99: 1364-7.

41 Charteris DG, Hiscott P, Robey HL, Gregor ZJ, Lightman SL, Grierson I. Inflammatory cells in proliferative vitreoretinopathy subretinal membranes. Ophthalmology 1993; 100: 43-6.

42 Limb GA, Franks WA, Munasinghe KR, Chignell AH, Dumonde DC. Proliferative vitreoretinopathy: an examination of the involvement of lymphocytes, adhesion molecules and HLA-DR antigens. Graefes Arch Clin Exp Ophthalmol 1993; 231: 331-36.

43 Scheifforth OF, Kamplik A, Gunther H, van der Mark K. Protein of the extracellular matrix in vitreoretinal membranes. Graefes Arch Clin Exp Ophthalmol 1988; 226: 357-61.

44 Hiscott P, Waller HA, Grierson I, Butler MG, Scott D. Local production of fibronectin by ectopic human retinal cells. Cell Tissue Res 1992; 267: $185-92$.

45 Johnson RN, Blankenship G. A prospective, randomised, clinical trial of heparin therapy for postoperative intraocular fibrin. Ophthalmology 1988; 95: 312-7.

46 Jaffe GF, Schwartz D, Han DP, Gottlieb M, Hartz A, McCarthy D, et al. Risk factors for postvitrectomy fibrin formation. Am F Ophthalmol 1990; 109: 661-7.

47 Vidaurri-Leal JS, Glaser BM. Effect of fibrin on morphologic characteristics of retinal pigment epithelial cells. Arch Ophthalmol 1984; 102: 1376-9.

48 Bregsen M, Martiny B, Weller M, Heimann K, Wiedemann P. Protein composition of human vitreous body: SDS PAGE and western blot of surgical and post-mortem samples. Fortschr Ophthalmol 1991; 88: $665-70$.

49 Jaccoma EH, Conway BP, Campochiaro PA. Cryotherapy causes extensive breakdown of the blood-retinal barrier: a comparison with argon laser photocoagulation. Arch Ophthalmol 1985; 103: 1728-30.

50 Campochiaro PA, Bryan JA, Conway B, Jaccoma EH. Intravitreal chemotactic and mitogenic activity. Implication of blood-retinal barrier breakdown. Arch Ophthalmol 1986; 104: 1685-7.

51 Mazure A, Grierson I. In vitro studies of the contractility of cell types involved in proliferative vitreoretinopathy. Invest Ophthalmol Vis Sci 1992; 33: 3407-16.

52 Glaser BM, Cardin A, Biscoe B. Proliferative vitreoretinopathy. The mechanism of development of vitreoretinal traction. Ophthalmology 1987 94: 327-32.

53 Campochiaro PA, Glaser BA. Platelet derived growth factor is chemotactic for human retinal pigment epithelial cells. Arch Ophthalmol 1985; 103: 576-9.

54 Burke JM, Abrams G, Aaberg T, Williams G. Chemotaxis and proliferation stimulating activities in human vitrectomy specimens: correlation with PVR severity. Invest Ophthalmol Vis Sci 1985; 26 (suppl): 283.

55 Burke JM. Cell interactions in proliferative vitreoretinopathy: do growth factors play a role? In: Heimann $\mathrm{K}$, Wiedemann $\mathrm{P}$, eds. Proliferative vitreoretinopathy. Heidelberg: Kaden, 1989: 80

56 Leschey KH, Hackett SF, Singer JH, Campochiaro PA. Growth factor responsiveness of human retinal pigment epithelial cells. Invest responsiveness of human retinal

57 Williams DF, Burke JM. Modulation of growth in retina-derived cells by extracellular matrices. Invest Ophthalmol Vis Sci 1990; 31: 1717-23.

58 Harvey AK, Roberge F, Hjelmeland LM. Chemotaxis of rat retinal glia to growth factors found in repairing wounds. Invest Ophthalmol Vis Sci 1987; 28: 1092-9.

59 Limb GA, Little BC, Meager A, Ogilvie JA, Wolstencroft RA, Franks WA et al. Cytokines in proliferative vitreoretinopathy. Eye 1991; 5: 686-93.

60 Glaser BM, Connor TB, Roberts AB, Sporn MB, Danielpoir D, Dart DD, et al. Correlation of fibrosis and transforming growth factor-beta type 2 levels in the eye. In: Heimann K, Weidemann P, eds. Proliferative vitreoretinopathy. Heidelberg: Kaden, 1989: 120 .

61 Gaudric A, Glacet-Bernard A, Falquerho L, Barritault D, Coscas G. Transforming growth factor beta in vitreous from patients with epiretinal proliferation. In: Heimann $\mathrm{K}$, Weidemann $\mathrm{P}$, eds. Proliferative vitreoproliferation. In: Heimann K, Weideman
retinopathy. Heidelberg: Kaden, 1989: 118.

62 Baudouin C, Fredj-Reygrobellet D, Brignole F, Negre F, Lapalus $P$, Gastaud P. Growth factors in vitreous and subretinal fluid cells from patients with proliferative vitreoretinopathy. Ophthalmic Res 1993; 25: 52-9.

63 Fredj-Reygrobellet D, Baudouin C, Negre F, Caruelle JP, Gastaud P, Lapalus P. Acidic FGF and other growth factors in preretinal membranes from patients with diabetic retinopathy and proliferative vitreoretinopathy. Ophthalmic Res 1991; 23: 154-61.

64 Malecaze F, Mathis A, Arne JL, Raulais D, Courtois Y, Hicks D. Localisation of acidic fibroblast growth factor in proliferative vitreoretinopathy membranes. Curr Eye Res 1991; 10: 719-29.

65 Robbins SG, Mixon RN, Wilson DJ, Hart CE, Robertson JE, Westra I et al. Platelet-derived growth factor ligands and receptors immunolocalised in proliferative retinal diseases. Invest Ophthalmol Vis Sci 1994 35: 3649-63.

66 Limb GA, Earley O, Jones SE, LeRoy F, Chignell AH, Dumonde DC. Expression of mRNA coding the TNF $\alpha$, IL1 $\beta$, and IL6 by cells infiltrating retinal membranes. Graefes Arch Clin Exp Ophthalmol 1994; 232: 646-51.

67 Baudouin C, Philip PJM, Brignole F, Elbouyermani A, Bayle J, Gastaud P. Immunolocalisation of interferon gamma in proliferative preretina tissues. Invest Ophthalmol Vis Sci 1993; 34 (suppl): 951

68 Proenca R, Carvalho M, Proenca D, Verissimo J, Regadas I, Travassos A. HLA antigens and lymphocytes in proliferative vitreoretinopathy. Graefes Arch Clin Exp Ophthalmol 1994; 232: 25-32.

69 Baudouin C, Fredj-Reygrobellet D, Baudouin F, Lapalus P, Gastaud P. Immunohistologic study of proliferative vitreoretinopathy. $A m \dot{j}$ Ophthalmol 1989; 108: 387-94.
70 Heidenkummer HP, Kamplik A. Intercellular adhesion molecule 1 (ICAM-1) and leukocyte function associated antigen-1 (LFA-1) expression in human epiretinal membranes. Graefes Arch Clin Exp Ophthalmol 1992; 230: 483-7.

71 Henley W, Okas S, Leopold I. Leukocyte migration inhibition by choroid and retina in retinal detachment. Ophthalmic Res 1975; 7: 129-35.

72 Brinkman CJJ, Broekhuyse RM. Cell-mediated immunity after retinal detachment as determined by leukocyte stimulation. Am $\mathcal{f}$ Ophthalmol 1978; 86: 260-2

73 Broekhuyse RM, Rademakers AJM, Van Vugt AHM, Winkers HJ. Autoimmune responsiveness to retinal IRBP, S-antigen and opsin in proliferative vitreoretinopathy. Exp Eye Res 1990; 50: 197-202.

74 Grisanti S, Heimann $K$, Wiedemann $P$. Immune response to specific molecules of the retina in proliferative vitreoretinal disorders. Graefes Arch Clin Exp Ophthalmol 1994; 232: 302-7.

75 Grisanti S, Wiedemann P, Weller M, Heimann K, Zilles K. The significance of complement in proliferative vitreoretinopathy. Invest Ophthalmo Vis Sci 1991; 32: 2711-7.

76 Liversidge J, Sewell HF, Forrester JV. Interactions between lymphocytes and cells of the blood-retina barrier: mechanisms of T lymphocyte adhesion to human retinal capillary endothelial cells and retinal pigment epithelial cells in vitro. Immunology 1990; 71: 390-6.

77 Forrester JV, Stott DI, Hercus KM. Naturally occurring antibodies to bovine and human retinal $S$ antigen: a comparison between uveitis bovine and human retinal $S$ antigen: a comparison between
patients and healthy volunteers. $B r \mathcal{F}$ Ophthalmol 1989; 73: 155-9.

78 Froebel KS, Armstrong SS, Cliffe AM, Urbaniak SJ, Forrester JV. An investigation of the general immune status and specific immune responsiveness to retinal $S$-antigen in patients with chronic posterior uveitis. Eye 1989; 3: 263-70.

79 Doekes G, van der Gaag R, Rothova A, van Kooyk Y, Broersma L, Zaa MJM, et al. Humoral and cellular immune responsiveness to human S-antigen in uveitis. Curr Eye Res 1987; 6: 909-19.

80 Gregerson DS, Abrahams IW, Puklin JE. Serum antibody responses to bovine retinal S-antigen and rod outer segments in proliferative diabetic retinopathy before and after argon laser photocoagulation. Ophthalmology 1982; 89: 327-68.

81 Vrabec TR, Reber RN, Magargal LE, Donoso LA. S-antigen Identification of human T-cell lymphocyte proliferative sites. Arch Ophthalmol 1990; 108: 1470-3.

82 Finkelstein SP, Caday CG, Klagsbrun M. The role of fibroblast growth factors in wound healing in the central nervous system. In: Janssen $\mathrm{H}$,
Rooman R, Robertson JIS, eds. Wound healing. Petersfield: Wrightson Biomedical Publishing Ltd, 1991: 41.

83 Wahl SM, Allen JB. T-lymphocyte dependent mechanisms of fibrosis. In: Barbul A, Pines E, Caldwell M, Hunt TK, eds. Growth factors and other aspects of wound he

84 Piguet PF, Collart MA, Grau GE, Sappino AP, Vassali P. Requirement of tumour necrosis factor for development of silica-induced pulmonary fibrosis. Nature 1990; 344: 245-7.

85 Kovacs EJ, Kelley J. Lymphokine regulation of macrophage-derived growth factor secretion following pulmonary injury. Am F Pathol 1985; 121: 261-8

86 Scott S, Pandolfi F, Kurnick JT. Fibroblasts mediate T cell survival: a proposed mechanism for retention of primed $T$ cells. $\mathcal{F} \operatorname{Exp} M e d 1990 ; 172$ 1873-6.

87 Kulozik M, Heckmann M, Mauch C, Scharffetter K, Krieg T. Cytokine regulation of collagen metabolism during wound healing in vitro and in vivo. In: Janssen H, Rooman R, Robertson JIS, eds. Wound healing. vetersfield: Wrightson Biomedical Publishing, 1991: 33.

88 Czaja MJ, Weiner FR, Eghbali M, Giambrone M-A, Zern MA. Differential effects of $\gamma$-interferon on collagen and fibronectin gene expression. $\mathcal{F}$ Biol Chem 1987; 262: 13348-51.

89 Melin M, Hartmann DJ, Majloire H, Falcoff E, Auriault C, Grimaud JA Human recombinant gamma-interferon stimulates proliferation and inhibits collagen and fibronectin production by human dental pulp fibroblasts. Cell Mol Biol 1989; 35: 97-110.

90 Ignotz RA, Massague J. Transforming growth factor- $\beta$ stimulates the expression of fibronectin and collagen and their incorporation into the extracellular matrix. $¥$ Biol Chem 1986; 261: 4337-45.

91 Postlethwaite AE, Raghow R, Sticklin GP, Poppleton H, Seyer JM, Kang AH. Modulation of fibroblast functions by interleukin 1: increased steady state accumulation of type I protocollagen messenger RNAs and stimulation of other functions but not chemotaxis by human recombinant interleukin $1 \alpha$ and $\beta$. $₹$ Cell Biol 1988; 106: 311-8.

92 Michels RG. Surgery of retinal detachment with proliferative vitreoretinopathy. Retina 1984; 4: 63-83.

93 Chen JC, Robertson JE, Coonan P, Blodi CF, Klein ML, Watzke RC, et al. Results and complications of pneumatic retinopexy. Ophthalmology 1988 95: 601-8.

94 Tornambe PE, Hilton GF, Kelly NF, Salzano TC, Wells JW, Wendel RT. Expanded indications for pneumatic retinopexy. Ophthalmology 1988; 95: 597-600.

95 Griffiths PG, Richardson J. Causes of proliferative retinopathy following pneumatic retinopexy. Arch Ophthalmol 1990; 108: 1515

96 Smiddy WE, Glaser BM, Michels RG, De Bustros S. Scleral buckle revision to treat recurrent rhegmatogenous retinal detachment. Ophthalmic Surg 1990; 21: 716-20.

97 Lewis H, Aaberg TM. Anterior proliferative vitreoretinopathy. Am $\mathcal{J}$ Ophthalmol 1988; 105: 277-84.

98 Lewis H, Aaberg TM, Abrams GW. Causes of failure after initial vitreoretinal surgery for severe proliferative vitreoretinopathy. Am $\mathcal{f}$ Ophthalmol $1991 ; 111$ : 8-14.

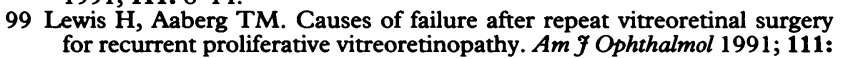
$15-9$.

100 Hanneken AM, Michels RG. Vitrectomy and scleral buckling methods for proliferative vitreoretinopathy. Ophthalmology 1988; 95: 865-9.

101 Blumenkranz MS, Azen SP, Aaberg T, Boone DC, Lewis H, Radtke N, et al. Relaxing retinotomy with silicone oil or long-acting gas in eyes with evere proliferative vitreoretinopathy. Silicone study report 5. Am $\mathcal{F}$ Ophthalmol 1993; 116: 557-64.

102 Federman JL, Eagle RC. Extensive peripheral retinectomy combined with posterior $360^{\circ}$ retinotomy for retinal reattachment in advanced proliferaposterior $360^{\circ}$ retinotomy for retinal reattachment in advanced prot
tive vitreoretinopathy cases. Ophthalmology 1990; 97: 1305-20. 
103 Chang S, Ozmert E, Zimmerman NJ. Intraoperative perfluorocarbon liquids in the management of proliferative vitreoretinopathy. $\mathrm{Am} \mathcal{f}$ Ophthalmol 1988; 106: 668-74.

104 Han DP, Rychwalski PJ, Mieler WF, Abrams GW. Management of complex retinal detachment with combined relaxing retinotomy and intrapitreal perfluoro-n-octane injection. Am $f$ Ophthalmol 1994; 118: 24-32.

105 The Silicone Study Group. Vitrectomy with silicone oil or sulphur hexafluoride gas in eyes with severe proliferative vitreoretinopathy: results of a randomised clinical trial. Silicone study report 1. Arch Ophthalmol 1992 110: 770-9.

106 The Silicone Study Group. Vitrectomy with silicone oil of perfluoropropane gas in eyes with severe proliferative vitreoretinopathy: results of
a randomised clinical trial. Silicone study report 2 . Arch Ophthalmol 1992; 110: 780-92.

107 Hutton WL, Azen SP, Blumenkranz MS, Lai M-Y, McCuen BW, Han DP, et al. The effects of silicone oil removal. Silicone study report 6 . Arch Ophthalmol 1994; 112: 778-85.

108 Lewis H, Burke JM, Abrams GW, Aaberg TM. Perisilicone proliferation after vitrectomy for proliferative vitreoretinopathy. Ophthalmology 1988; 95: 583-91.

109 Federman JL, Schubert HD. Complications associated with the use of silicone oil in 150 eyes after retina-vitreous surgery. Ophthalmology 1988; 95: 870-6.

110 Leaver PK, Grey RHB, Garner A. Silicone oil injection in the treatment of massive pre-retinal retraction. II Late complications in 93 eyes. $\mathrm{Br} \mathscr{f}$ Ophthalmol 1979; 63: 361-7.

111 Lean JS, Van Der Zee WAM, Ryan SJ. Experimental model of proliferative vitreoretinopathy (PVR) in the vitrectomised eye: effect of silicone oil. $B r$ vitreoretinopathy (PVR) in the

112 Gonvers $M$, Thresher $R$. Temporary use of silicone oil in the treatment of proliferative vitreoretinopathy: an experimental study with a new animal model. Graefes Arch Clin Exp Ophthalmol 1983; 221: 46-53.

113 Fastenberg DM, Diddie KR, Delmage JM, Dorey K. Intraocular injection of silicone oil for experimental proliferative vitreoretinopathy. Am Ophthalmol 1983; 95: 663-7.

114 Lambrou FH, Burke JM, Aaberg TM. Effect of silicone oil on experimental traction retinal detachment. Arch Ophthalmol 1987; 105: 1269-72.

115 Michels RG, Wilkinson CP, Rice TA. Retinal detachment. St Louis: Mosby, 1990: 704-6.

116 Andenmatten $R$, Gonvers $M$. Sophisticated vitreoretinal surgery in patients with a healthy fellow eye. Graefes Arch Clin Exp Ophthalmol 1993; 231: 495-9.

117 McCormack P, Simcock P, Charteris DG, Lavin MJ. Is surgery for proliferative vitreoretinopathy justifiable? Eye 1994; 8: 75-6.

118 Blumenkranz MS, Ophir A, Claflin AJ, Hajek A. Fluorouracil for the treatment of massive periretinal proliferation. Am f Ophthalmol 1982; 94: 458-67.

119 Stern WH, Lewis GP, Erickson PA, Guerin CJ, Anderson DH, Fisher SK et al. Fluorouracil therapy proliferative vitreoretinopathy after vitrecet al. Fluorouracil therapy proliferative

120 Stern WH, Guerin CJ, Erickson PA, Lewis GP, Anderson DH, Fisher SK. Ocular toxicity of fluorouracil after vitrectomy. Am $\mathcal{f}$ Ophthalmol 1983; 96: 43-51.

121 Blankenship GW. Evaluation of a single intravitreal injection of 5-fluorouracil in vitrectomy cases. Graefes Arch Clin Exp Ophthalmol 1989; 227: 565-8.

122 Blumenkranz MS, Hernandez E, Ophir A, Norton EWD. 5-Fluorouracil: new applications in complicated retinal detachment for an established antimetabolite. Ophthalmology 1984; 91: 122-30.

123 Khawly J, Saloupis P, Hatchell D, Machemer R. Daunorubicin treatment in a refined experimental model of proliferative vitreoretinopathy. Graefes in a refined experimental model of proliferative

124 Wiedemann $P$, Lemmen $K$, Schmiedl R, Heimann $K$. Intraocular daunorubicin for the treatment and prophylaxis of traumatic proliferative vitreoretinopathy. Am $f$ Ophthalmol 1987; 104: 10-4

125 Wiedemann P, Leinung C, Hilgers RD, Heimann K. Daunomicin and silicone oil for the treatment of proliferative vitreoretinopathy. Graefes Arch Clin Exp Ophthalmol 1991; 229: 150-2.

126 Wiedemann P, Heimann K. Proliferative vitreoretinopathy. Curr Opin Ophthalmol 1992; 3: 357-65.

127 Barrada A, Peyman GA, Greenberg D, Stelmack T, Fiscella R. Toxicity of antineoplastic drugs in vitrectomy infusion fluids. Ophthalmic Surg 1983, 14: 845-7.

128 Ohuchi T, Kuriyama S, Yoshimura N, Honda Y, Hiraoka M, Abe M. The effect of X-ray irradiation on human retinal pigment epithelial cell proliferation. Graefes Arch Clin Exp Ophthalmol 1991; 229: 75-8.

129 Kuriyama S, Ohuchi T, Yoshimura N, Honda Y, Hiraoka M, Abe M Evaluation of radiation therapy for experimental proliferative vitreoretinopathy in rabbits. Graefes Arch Clin Exp Ophthalmol 1990; 228 : 552-5.

130 Binder S, Bonnet M, Velikay M, Gerard JP, Stolba U, Wedrich A, et al. Radiation therapy in proliferative vitreoretinopathy. A prospective
randomised study. Graefes Arch Clin Exp Ophthalmol 1994; 232: 211-4.

131 Campochiaro PA, Hackett SF, Conway BP. Retinoic acid promotes density-dependent growth arrest in human retinal pigment epithelial density-dependent growth arrest in human reting
cells. Invest Ophthalmol Vis $S c i$ 1991; 32: 65-72.

132 Araiz JJ, Refojo MF, Arroyo MH, Leong FL, Albert DM, Tolentino FI. Antiproliferative effect of retinoic acid in intravitreous silicone oil in an animal model of proliferative vitreoretinopathy. Invest Ophthalmol Vis $\mathrm{Sci}$ 1993; 34: 522-30.

133 Giordano GG, Refojo MF, Arroyo MH. Sustained delivery of retinoic acid from microspheres of biodegradable polymer in PVR. Invest Ophthalmol Vis Sci 1993; 34: 2743-51.

134 Ferkat S, de Juan E, Campochiaro PA. The effect of oral 13-cis-retinoic acid on retinal attachment after surgical repair in eyes with proliferative
vitreoretinopathy. Invest Ophthalmol Vis $S c i$ 1994; 35 (suppl): 1532.

135 Daniels SA, Coonley KG, Yoshizumi MO. Taxol treatment of experimental proliferative vitreoretinopathy. Graefes Arch Clin Exp Ophthalmol 1990; 228: 513-6.

136 Weller M, Wiedemann $P$, Moter $H$, Heimann $K$. Transferrin and transferrin receptor expression in intraocular proliferative disease: APAAPimmunolabeling of retinal membranes and ELISA for vitreal transferrin. Graefes Arch Clin Exp Ophthalmol 1989; 227: 281-6.

137 Jaffe GJ, Earnest K, Fulcher S, Lui GM, Houston LL. Antitransferrin receptor immunotoxin inhibits proliferating human retinal pigment epithelial cells. Arch Ophthalmol 1990; 108: 1163-8.

138 Blumenkranz MS, Claflin A, Hajek AS. Selection of therapeutic agents for intraocular proliferative disease. Arch Ophthalmol 1984; 102: 598-604.

139 Peyman GA, Schulman J. Proliferative vitreoretinopathy and chemotherapeutic agents. Surv Ophthalmol 1985; 29: 434-42.

140 Tano Y, Sugita G, Abrams G, Machemer R. Inhibition of intraocular proliferation with intravitreal corticosteroids. Am $\mathcal{F}$ Ophthalmol 1980; 89. 131-6.

141 Tano Y, Chandler D, Machemer R. Treatment of intraocular proliferation with intravitreal injection of triamcinolone acetonide. Am $\mathcal{f}$ Ophthalmol 1980; 90: 810-6.

142 Chandler DB, Hida $T$, Sheta $S$, Proia $A D$, Machemer R. Improvement in efficacy of corticosteroid therapy in an animal model of proliferative vitreoretinopathy by pretreatment. Graefes Arch Clin Exp Ophthalmol 1987; 225: 259-65.

143 Koerner F, Merz A, Gloor B, Wagner E. Post operative retinal fibrosis - a controlled clinical study of systemic steroid therapy. Graefes Arch Clin Exp Ophthalmol 1982; 219: 268-71.

144 Paris C, Peyman G, Cremillion C, Bluder K. Intravitreal dexamethasone following vitreous surgery. Int Ophthalmol 1991; 15: 173-4.

145 Pearson PA, Enyedi LB, Jaffe GJ, Ashton P. Sustained delivery of cyclosporine (CsA) and dexamethasone (dex) in the treatment of experimental proliferative vitreoretinopathy. Invest Ophthalmol Vis Sci 1994; 35 (suppl): 1923 .

146 Blumenkranz MS, Hartzer MK. Pharmacologic treatment of proliferative vitreoretinopathy: interrelationship with the coagulation cascade. In: Lewis H, Ryan SJ, eds. Medical and surgical retina, advances, controversies and management. St Louis: Mosby, 1993: 172.

147 Iverson DA, Katsura H, Hartzer MK, Blumenkranz MS. Inhibition of intraocular fibrin formation following infusion of low-molecular-weight heparin during vitrectomy. Arch Ophthalmol 1991; 109: 405-9.

148 Chapman C, Iverson D, Hartzer M, Minelli E, Blumenkranz MS. The effect of low-molecular-weight heparin on proliferative vitreoretinopathy induced in the rabbit eye. Invest Ophthalmol Vis Sci 1992; 33 (suppl): 855 .

149 Williams GA, Lambrou FH, Jaffe GA, Snyder RW, Green GDJ, Devenyi RG, et al. Treatment of postvitrectomy fibrin formation with intraocular tissue plasminogen activator. Arch Ophthalmol 1988; 106: 1055-8.

150 Leschey KH, Hines J, Singer JH, Hackett SF, Campochiaro PA. Inhibition of growth factor effects in retinal pigment epithelial cells. Invest Ophthalmol Vis Sci 1991; 32: 1770-8.

$151 \mathrm{Kim}$ RY, Stern WH. Retinoids and butyrate modulate fibroblast growth and contraction of collagen matrices. Invest Ophthalmol Vis Sci 1990; 31: 1183-6.

152 Lemor M, De Bustros S, Glaser BM. Low dose colchicine inhibits astrocyte, fibroblast and RPE cell migration and proliferation. Arch cyte, fibroblast and RPE cell

153 Lemor M, Yeo JH, Glaser BM. Oral colchicine for the treatment of experimental traction retinal detachment. Arch Ophthalmol 1986; 104: 1226-9.

154 Berman DH, Gombos GM. Proliferative vitreoretinopathy: does oral low dose colchicine have an inhibitory effect? A controlled study in humans. Ophthalmic Surg 1989; 20: 268-72.

155 Rubsamen PE, Davis PA, Hernandez E, O'Grady GE, Cousins SW. Prevention of experimental proliferative vitreoretinopathy with a biodegradable intravitreal implant for the sustained release of fluorouracil. Arch Ophthalmol 1994; 112: 407-13.

156 Hashizoe M, Ogura Y, Kimura H, Moritera T, Honda Y, Kyo M, et al. Scleral plug of biodegradable polymers for controlled drug release in the vitreous. Arch Ophthalmol 1994; 112: 1380-4.

157 Anand R, Nightingale SD, Fish RH, Smith TJ, Ashton P. Control of cytomegalovirus retinitis using sustained release of intraocular ganciclovir. Arch Ophthalmol 1993; 111: 223-7.

158 Morton DF, Parks DJ, Mellow SD, Ferris FL, Waiton RC, Remaley NA, et al. Treatment of cytomegalovirus retinitis with an intraocular sustained-release ganciclovir implant. Arch Ophthalmol 1994; 112: 1531-9.

159 Arroyo MH, Refojo MF, Araiz J, Tolentino FI, Caiita VN, Elner VM. Silicone oil as a delivery vehicle for BCNU in rabbit proliferative vitreoretinopathy. Retina 1993; 13: 245-50.

160 Nakagawa M, Doi M, Refojo MF, Leong FL, Tolentino FI. Antiproliferative effect of retinoic acid in silicone/fluorosilicone copolymer oil in a fibroblast platelet animal model of PVR. Invest Ophthalmol Vis Sci 1994; 35 (suppl): 1923. 